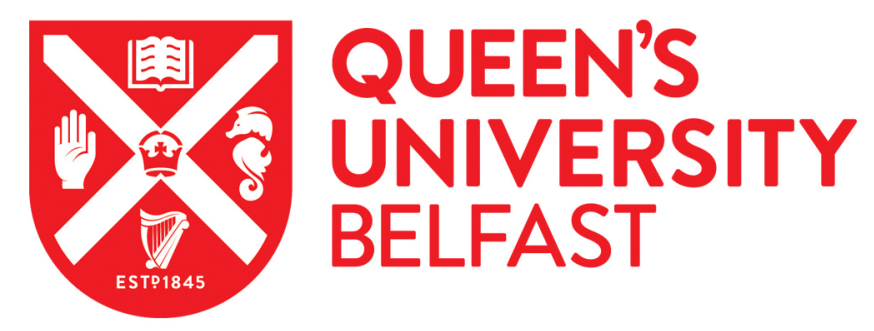

\title{
The migrant crisis and the importance of developing cultural competence in the intensive care unit
}

Benbenishty, J., Gutysz-Wojnicka, A., Harth, I., Barkestad, E., Satosek, D., Jacobsson, K., \& Blackwood, B. (2017). The migrant crisis and the importance of developing cultural competence in the intensive care unit. Nursing in Critical Care, 22(5), 262-263. https://doi.org/10.1111/nicc.12313

Published in:

Nursing in Critical Care

Document Version:

Peer reviewed version

Queen's University Belfast - Research Portal:

Link to publication record in Queen's University Belfast Research Portal

Publisher rights

Copyright 2017, Wiley. This work is made available online in accordance with the publisher's policies. Please refer to any applicable terms of use of the publisher.

\section{General rights}

Copyright for the publications made accessible via the Queen's University Belfast Research Portal is retained by the author(s) and / or other copyright owners and it is a condition of accessing these publications that users recognise and abide by the legal requirements associated with these rights.

Take down policy

The Research Portal is Queen's institutional repository that provides access to Queen's research output. Every effort has been made to ensure that content in the Research Portal does not infringe any person's rights, or applicable UK laws. If you discover content in the Research Portal that you believe breaches copyright or violates any law, please contact openaccess@qub.ac.uk. 
Editorial Title: The migrant crisis and the importance of developing cultural competence in the Intensive Care Unit

Authors and affiliations:

Julie Benbenishty, Academic Consultant Trauma Coordinator, Hadassah Hebrew University Medical Center, PO Box 12000, Ein Kerem, Jerusalem Israel 9120

Dr Aleksandra Gutysz-Wojnicka, Lecturer, Department of Nursing, Faculty of Medical Sciences, University of Warmia and Mazury, Zolnierska 14c Street, 10-561 Olsztyn, Poland

Irene Harth, Senior Staff Nurse, Paediatric Intensive Care, University Medicine Mainz Center for Child and Adolescent Medicine, 109 AE2 Langenbeckstr. 1, D-55101 Mainz, Germany

Eva Barkestad, Head of Post Graduate Education at the ICU, Danderyd's Hospital, Anesthesia and Intensive Care Department, 18288 Stockholm, Sweden

Drago Satosek, Registered Nurse, University Medical Center Ljubjana, Department of Cardiology, Zaloska c. 7, 1000 Ljubljana, Slovenia

Kaisa Jacobsson, ICU Nurse, Teho-osasto (ICU) 20, PL 340, 00029 HUS, Finland

Dr Bronagh Blackwood, Professor Critical Care Research, Centre for Experimental Medicine, Queen's University Belfast, Wellcome-Wolfson Building, 97 Lisburn Road, Belfast BT9 7BL, UK

Culture plays a large role in shaping an individual's health-related values, beliefs, behavior and situational judgment in general (Unger, 2012). In healthcare organisations, poorly handled cross-cultural communication can lead to negative social and clinical consequences, an environment of uncertainty or misunderstanding, bewilderment for the patient and family, ordering unnecessary investigations, patient non-compliance, delays in obtaining informed consent and an inferior quality of care (American College of Physicians, 2004). Cultural competence, therefore, is fundamental to clinical care. It is central to professionalism and, not unlike empathy, an element of care that, if not instinctively forthcoming in every health professional, can at least be taught (Manojlovich, 2002). Cultural awareness is a growing health care issue and a significant challenge for healthcare professionals. People are not simply immigrating from country to country for economic reasons or for work. Large numbers of refugees are migrating, some have fled persecution, had harrowing journeys, and had previous negative experiences with healthcare professionals. Whatever the reason, there is little doubt that their experiences are hugely 
varied and this impacts on their perception of the way in which they are treated by everyone, not least, while they are ill, vulnerable and effectively in 'someone else's care'.

Certain environments add to the disorientation and even fear that patients experience. A trauma patient, for example who is the victim or even the perpetrator of a crime may be overwhelmed by the number of healthcare workers attending him or her, the bright lights in the emergency department, the number of voices around them, their clothes being cut away, clinical examination by a multi-disciplinary team. This, added to the trauma of being a victim of a crime or being found out, adds to the stress of their medical experience. It is not unusual in these instances for conscious patients to fail to respond to any questions at all clinical or otherwise. Such reticence presents a problem to clinical staff who find themselves ordering multiple investigations in order to find out essential information that they might otherwise learn by having the opportunity to communicate effectively with the patient. For patients in the Intensive Care Unit (ICU), with continuous background noise and activity, sleep is invariably disturbed and disorientation is compounded by illness and sedatives. Cultural awareness with regard to personal care is crucial here, where patients may not have the strength to express their sentiments but are aware of all physical contact. A Norwegian study reported that ICU staff felt culturally challenged when dealing with migrant families and found a "conflict between professional nursing practice and family cultural traditions" (Høye, 2010). Conflict results in an inevitable clash between behaviors of a dominant and a non-dominant culture.

The challenge for nurses is to assess core cross-cultural issues in the care of each patient using the following skills: exploration of the meaning of the illness to the patient; determination of the social context in which the patient lives; engagement in negotiation with the patient to encourage effective communication and adherence to treatment; and exploration of their perceptions of the treatment they receive. Being a culturally competent nurse is not easy. We must first come to terms with our own personality traits, prejudices and perceptions in order to then overcome them. From verbal to non-verbal communication, from conscious to subconscious thought and from secular to religious beliefs, we have to strive for culturally competent care for every patient at a personal and institutional level. 
To assist ICU nurses address these challenges within Europe, the European Union funded Erasmus+ project on 'Multicultural Care in European Intensive Care Units (MICE-ICU)' was developed (http://mice-icu.eu/). It aims to improve knowledge, skills and competencies of ICU nurses in cultural sensitive care by developing and providing online access to a specialist, accredited multicultural course for ICU Nurses. It was initiated by three nursing organizations: the Polish Society of Anesthesiology and Intensive Nursing Care (PTPAilO); the College of Nursing in Celje (Slovenia); the University of Ostrava, Czech Republic; and is supported by the European federation of Critical Care Nursing associations (EfCCNa), Danmar Computers, a private company providing vocational training in the field of Information Technology and Assist International HR, an organization with focus on blended learning in virtual environments (e-learning, webinars, e-tutorials \& face-to-face). The project started on October 1, 2016 and will be finished September 2018.

The value of the MICE -ICU project is that it aims to respond to the internationally recognized importance of developing cultural competence in the intensive care unit. Europe is becoming more multicultural and is full of new challenges in the context of the migrant crisis. Strategic cooperation and exchange of experiences and good practice between nurses, researchers, and teachers from different countries are needed and seem to be the best way to prepare recommendations in the field of providing culturally sensitive intensive nursing care. MICE-ICU provides such an opportunity and EfCCNa plays a vital role in this process. 


\section{References}

Unger J.B. \& Schwartz S.J. (2012). Conceptual considerations in studies of cultural influences on health behaviors. Preventive Medicine, 55(5): 353-355

Manojlovich M. \& Ketefian S. (2002). The effects of organizational culture on nursing professionalism: Implications for health resource planning. Canadian Journal of Nursing Research, 33(4): 15-34

Groman R., Ginsburg J., American College of Physicians. (2004). Racial and Ethnic Disparities in Health Care. A Position Paper of the American College of Physicians. Annals Internal Medicine, 141: 226-232

Høye S. \& Severinsson E. (2010). Professional and cultural conflicts for intensive care nurses. Journal of Advanced Nursing, 66(4): 858-867 